(C) К. Деммер

\title{
ГОРНЯЦКИЙ НАЦИОНАЛИЗМ, НИКЕЛЕВАЯ ПРОМЫШЛЕННОСТЬ И ДЕКОЛОНИЗАЦИЯ В НОВОЙ КАЛЕДОНИИ
}

Ключевые слова: Новая Каледония, канаки, деколонизация, Нумейское соглашение, Концепция восстановления экономического равновесия, контроль над ресурсами, никелевая промышленность, канакский социализм, горняцкий национализм, референдум.

\begin{abstract}
Задача этой статьи - продемонстрировать, что шахты стали для канаков Новой Каледонии опытным полем деколонизации, параллельно с начатой 30 лет назад институциональной деколонизацией. Мы рассмотрим основные этапы и формы завоевания сторонниками независимости главного ресурса архипелага - никеля. Подчеркнем, что взятие ими под контроль мультинационального предприятия - Южнотихоокеанской горнодобывающей компании - глубоко изменило сектор горнодобычи, где новые металлургические гиганты теснят местные предприятия, экспортирующие сырье. Помимо этого, мы проанализируем особенности деколонизации этой заморской “страны” в свете референдумов о самоопределении, завершающих процесс национального освобождения, начатый подписанием Нумейских соглашений 1998 г.
\end{abstract}

\section{Канакское предприятие в центре процесса освобождения}

Новая Каледония - французское владение с середины XIX в. - обладает 15\% мировых запасов никеля (второе место после Австралии, наиболее богатой этим металлом). Она находится на пятом месте в мире по производству “зеленого золота” - ее главного полезного ископаемого. В отдельные годы доля никеля в ее экспорте доходит до 90\% и дает до 10\% ВВП (CEROM 2015). Имея такое богатство, канаки подкрепили свое требование независимости установлением контроля над этим ресурсом в результате бурного периода 1980-х гг., отмеченного их столкновениями (порой смертельными) с потомками колонизаторов за реституцию конфискованных земель. С возвращением мира, зафиксированного Матиньонскими (1988), а позже - Нумейскими соглашениями (1998), стратегия Фронта освобождения канаков на первом этапе сводилась к контролю над шахтами путем выкупа Южнотихоокеанской горнодобывающей компании (Société minière du Sud Pacifique - SMSP, далее - ЮТГДК) а с 2000 гг. - к переработке никеля на метал-

Кристина Деммер | https://orcid.org/0000-0001-6998-0746 | Центр Норберта Элиаса | 2 rue de la Charité, 13002 Marseille, France | christine.demmer@univ-amu.fr

Статья впервые опубликована в журнале “Cahiers Jaurès”, 2018, 230 (4): 35-52. На русском языке пу-

бликуется с согласия автора и редакции журнала.

Для цитирования: К. Деммер. Горняцкий национализм, никелевая промышленностьи деколонизация в новой каледонии. // Антропологии/Anthropologies. 2021. № 1. С. 49-61. https://doi.org/10.33876/27823423/2021-1/49-61. 
лургических заводах Новой Каледонии и в офшорах, где большинство капитала горнодобывающих компаний принадлежит канакам.

Этот горняцкий национализм канаков неотделим от политической борьбы: он сопровождает на разных этапах институциональный процесс деколонизации. Прежде всего, именно соглашения 1988 г. зафиксировали факт выкупа ЮТГДК, с финансовой помощью государства, у политика-лоялиста Ж. Лафлера. Этот выкуп символизировал центральное понятие Матиньонских соглашений: “восстановление экономического равновесия” между канаками и остальным населением путем создания трех провинций, наделенных существенной политической и экономической автономией (Северной провинции и Провинции островов Луайоте, населенных в основном канаками, а также Южной провинции, куда входит столичный город Нумеа, с преимущественно неканакским населением) ${ }^{1}$. В дальнейшем Берсийские соглашения (1 февраля 1998), давшие начало проекту “Северного завода”, целью которого было содействие увеличению богатства территории в перспективе обретения ею независимости, стало предварительным условием для подписания Нумейского соглашения 5 мая того же года.

Требование независимости стало выдвигаться с 1996 г., когда начались дискуссии о выходе из Матиньонских соглашений не через референдум, а путем получения нового статуса. В 1997 г., после многочисленных шахтерских забастовок, тогдашний премьерминистр Л. Жоспен, вопреки позиции министерства Экономики и финансов, пошел навстречу требованиям канаков, дав зеленый свет металлургическому производству ЮТГДК. Вскоре после этого, в 1998 г., возобновились обсуждения деколонизационного соглашения. Оно предполагает постепенную и безвозвратную передачу управления (за пределами области исключительных полномочий центральной власти) правительству Новой Каледонии ${ }^{2}$, а также организацию ново-каледонского гражданства, юридически базирующегося на местном электоральном корпусе, отличном от общего корпуса избирателей, и дающего преимущества при трудоустройстве; наконец, соглашение предусматривает выход из него путем трех референдумов о самоопределении, первый из которых состоялся 4 ноября 2018 г., когда 56\% проголосовавших высказались против независимости, второй - 4 октября 2020 года (53\% голосов “против”). Третий и последний референдум должен состояться, согласно Нумейскому соглашению, в 2022 г. На всем протяжении истекших 20 лет основной задачей ЮТГДК было восстановление экономического равновесия, заложенное в тексте Матиньонского и Нумейского соглашений. Для исполнения этой задачи предприятие построило и запустило Северный металлургический завод, а также установило партнерские отношения с мультинациональными металлургическими предприятиями азиатского региона.

В дальнейшем изложении нас будет интересовать не столько классическая геополитическая составляющая проблемы, связанная с соотношением уже достигнутого суверенитета и контроля над ресурсами, сколько “горняцкий путь” построения постколониального государства, которое формируется еще до избавления от опеки бывшего колонизатора. Точнее, экспансия ЮТГДК и вытекающая из нее реорганизация никелевой промышленности настолько же участвуют в процессе деколонизации, очерченной четкими политическими и временными рамками Нумейского соглашения, насколько свидетельствуют о нетипичности этого процесса. Изначально предприятие оказалось инструментом в борьбе за возвращение институционального суверенитета: демонстрируя способность канаков “заниматься экономикой” (в данном случае - быть игроками мирового рынка никеля еще до обретения независимости), оно стало дополнительным аргументом в пользу права колонизованных народов распоряжаться своей судьбой. Затем оно сыграло важную роль в изменении соотношения сил внутри страны, открыв канакам 
доступ к сферам экономики и политики. Наконец, компания стала предвестником новых отношений взаимозависимости, таких, которые может иметь суверенное государство - особенно если последнее рождается в эпоху быстрого роста межнациональных горнодобывающих предприятий - превратив эти партнерские отношения в орудие эмансипации.

Чтобы показать, почему борьба за контроль над добычей и производством никеля стала одним из необходимых условий экономического и политического переустройства постколониального новокаледонского государства, я подробно рассмотрю основные этапы этой борьбы, выявлю ее влияние на организацию никелевой промышленности - и тем самым продемонстрирую особенности деколонизации, переживаемой сегодня Новой Каледонией. Недавний конфликт между горнодобывающими предприятиями и местным правительством является хорошей иллюстрацией того, что добыча и производство никеля находятся в эпицентре экономического и политического соперничества.

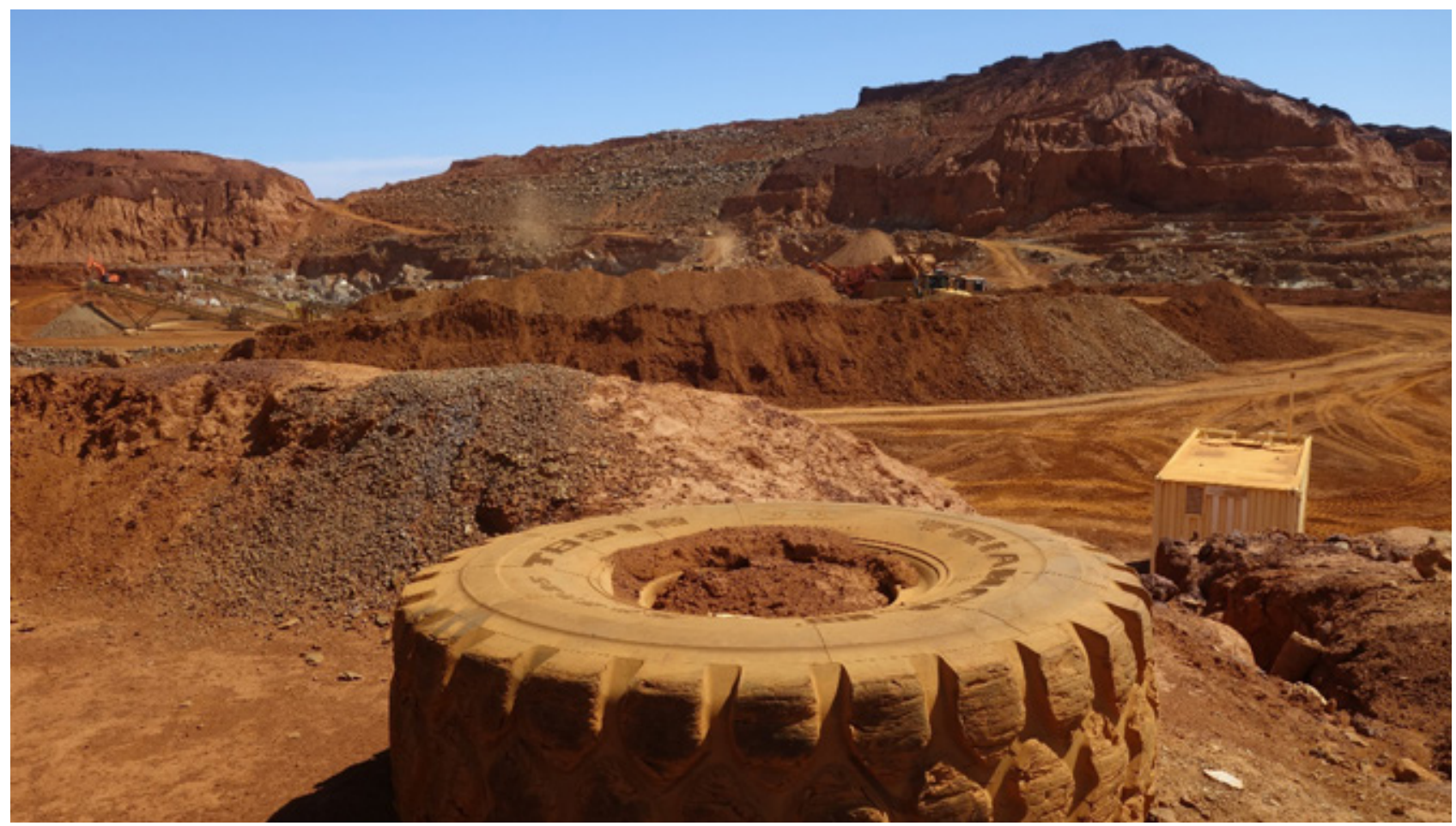

Шахта Никелевой горнодобывающей компании - филиала ЮТГДК (Накети, Канала).

Фото автора (2017)

\section{Этапы горняцкого национализма}

Когда в середине 1970-х гг. молодые политические партии канаков заговорили о независимости территории, их требования поначалу концентрировались на признании канакской культуры и перераспределении земель. К 1984 г. разрозненные политические движения сформировали Национальный социалистический фронт освобождения канаков (Front de Libération Kanak et Socialiste - FLNKS), далее - НСФОК, решительно настроенный на завоевание независимости в кратчайшие сроки. После восстания, вспыхнувшего осенью того же года в знак протеста против особого статуса, предложенного Новой Кадедонии французским государством, и закончившегося гибелью лидера восставших Элуа Машоро в ходе его подавления, сторонники независимости, понимая невозможность длительной вооруженной борьбы, встали на путь экономического национализма в рамках так называемого Статуса регионов (1985-1988). Впер- 
вые оказавшись во главе местных сообществ, они принялись за “конструирование канакского”, запустив крупные проекты в сфере туризма и агропищевого сектора, а также микропроекты на землях резерваций, куда были оттеснены их предки в ходе французской поселенческой колонизации (см. Demmer 2016). Эта всеобщая мобилизация, несущая на себе отпечаток утопической идеи освобождения действием, заложила основу политико-экономического подхода, который был поставлен на службу подготовке к независимости. На следующих этапах эта составляющая исчезает, но остается более прагматичная (и парадигматическая для борьбы канаков за освобождение) идея инвестирования в рыночную экономику бывшими садоводами, жившими натуральным хозяйством, которое еще в начале 1980-х гг. наполовину обеспечивало потребности семей в продовольствии. Это было необходимым условием для того, чтобы взять в свои руки экономику, находящуюся под контролем бывших колонизаторов и существенно зависящую от трансферов из метрополии (Freyss 1995). Говоря конкретно, нужно было бороться с экономическим и социальным иждивенчеством, продвигая развитие предпринимательства среди канаков. Эта флагманская идея канакского национализма многим обязана Рафаэлю Пиджо, получившему высшее образование в сфере экономики и финансов и ставшему первым генеральным директором ЮТГДК, инициатору строительства Северного завода, активисту первой канакской партии - Каледонского союза (Union Calédonienne - UC) и соратнику ЖанаМари Тжибау, основателя и руководителя НСФОК, подписавшего Матиньонское соглашение 1988 г.

Именно эти два человека решили инвестировать в никелевую промышленность, сосредоточив внимание на контроле над горнодобывающей компанией, который они получили благодаря Матиньонскому соглашению и который подтолкнул сторонников независимости к добыче никеля начиная с 1990 г. На протяжении предшествующего десятилетия их проект общественного переустройства носил имя “канакского социализма", что предполагало своего рода коллективизацию предприятий наряду с их национализацией (на субгосударственном уровне, т.е. на уровне кланов или племен). Финансовый пакет ЮТГДК по-своему отвечает этим требованиям: 87\% акций принадлежит Финансово-инвестиционной компании Северной провинции (Société de financement et d'investissement de la province Nord - SOFINOR), в которой доля государственного капитала составляет 75\%, что позволяет депутатам - сторонникам независимости, находящимся в местном парламенте в большинстве, быть членами совета директоров предприятия ${ }^{3}$. Последнее быстро стало важным игроком на рынке никеля, первым экспортером этого металла в Новой Каледонии и вторым по производству оксида никеля в мире.

Но сторонники независимости на этом не останавливаются. Согласно пожеланию лидера НСФОК Ж.-М. Тжибау, высказанному им незадолго до смерти в 1989 г., их главным делом становится развитие металлургической промышленности, которая должна позволить получить максимальную прибыль от никеля, по примеру других производящих стран. С 1992 г. этот вопрос начинает обсуждаться на съездах НСФОК. Националисты заявляют о своем намерении построить завод на севере страны. В 1995 г. ЮТГДК удается убедить крупную канадскую фирму “Фальконбридж” организовать совместное предприятие с небывалым соотношением акций: на ее долю приходится 51\% против 49\% у канадского гиганта. Взамен ЮТГДК обещает обеспечить источник сырья, для чего ей приходится искать новое месторождение. Националисты предлагают старейшему промышленному предприятию - “Компании Никель” (Société Le Nickel - SLN) - обменять горный массив в регионе Пум, менее богатый никелем, на более богатый Тьебаги, чтобы построить рядом завод. “Никель”, поддерживаемый лоялистами, отказывается. Начинаются долгие переговоры между, с одной стороны ЮТГДК и КФСНО, с другой -“Компанией Никель” и государством в лице французской многонациональной горнодобыва- 
ющей и металлургической компании “Эрамет”. В конце концов в результате Берсийских соглашений ЮТГДК получает другой массив - Кониамбо, на условии начать инвестиции, совместно c “Фальконбриджем”, не позднее 1 января 2006 г. (David, Sourisseau 2016: 23-69). AО “Кониамбо Никель”, совместное с ЮТГДК предприятие для разработки нового месторождения, создается точно в установленный срок, а с 2012 года оно начинает производить ферроникелевый сплав с достаточно высоким содержанием никеля. Тут снова встает на повестку дня вопрос о канакском предпринимательстве на уровне общин, однако сепаратистские лидеры продвигают организацию-субподрядчика, созданную предприятиями так называемых “народных акционеров" (компаниями с ограниченной ответственностью, превращенными в филиалы Финансово-инвестиционной компании Северной провинции; эти мелкие акционеры были отобраны таким образом, чтобы обеспечить представительство кланов или вождеств $)^{4}$.

Тем временем развертывание металлургической стратегии с опорой на мировой капитал продолжается. ЮТГДК создает совместное предприятие на тех же условиях (51:49\% акций) с южнокорейской сталелитейной группой Поско (Société du Nickel de la Nouvelle-Calédonie et Corée Co Ltd - SNNC), которая с 2008 года перерабатывает на своем заводе в Кванъяне каледонийскую руду с менее высоким содержанием никеля, чем на месторождении Кониамбо. Этот союз символизирует новый поворот в истории ЮТГДК, которая отныне становится в основном металлургическим предприятием, тогда как ее шахты (кроме Кониамбо) отходят вновь созданному совместному предприятию “Никелевая горнодобывающая компания”. Корейская группа пользуется отныне регулярными поставками каледонийского никеля, а “канакский” холдинг обеспечивает надежный сбыт своего минерального сырья. Прощупав ситуацию, в марте 2018 г. ЮТГДК подписала “Меморандумное соглашение” с китайским производителем никеля (Yangzhou Yichuan Nickel Industry Co Ltd), сохранив за собой, как и в других случаях, контрольный пакет акций предприятия. Согласно стратегическому плану сторонников независимости, металлургические совместные предприятия, в которых ЮТГДК является мажоритарным акционером, должны возвращать в страну в форме дивидендов добавочную стоимость, произведенную в результате переработки минерального сырья в металл. В октябре 2015 г., например, рентабельность совместного с Южной Кореей предприятия была более чем в десять раз выше продажной цены сырья (Exportations 2015). Вся Северная провинция должна получать от этого выгоду благодаря реинвестициям Финансово-инвестиционной компании. Однако цель развития территорий, которую поставила перед собой ЮТГДК и которая обеспечивает компании поддержку со стороны государства и благосклонность сторонников более широкой автономии в самой Новой Каледонии, - не единственная в канакском никелевом проекте.

Фронт освобождения канаков стремится воспроизвести региональную схему на “национальном” уровне. Так, ему удалось включить во вторую версию Берсийских соглашений от 1999 г. передачу части акций компании “Никель” государственной структуре, совместно управляемой представителями трех провинций: “Каледонской промышленной акционерной компании/ КПАК” (Société Territoriale Calédonienne de Participations Industrielles - STCPI). С 2007 г. последней принадлежит блокирующий миноритарный пакет (34\% акций). С начала 2000-х годов компания “Никель” выплатила этой структуре в качестве дивидендов 40 млрд тихоокеанских франков ${ }^{5}$. Задача, разделяемая и преимущественно “белой” автономистской партией “Единая Каледония”, состоит в том, чтобы в перспективе у КПАК был 51\% акций “Компании Никель”. Эта часть стратегии дополняет более широкую политическую цель национализации всего никеля (сырого и переработанного), с тем чтобы доходы добывающих и перерабатывающих предприятий шли в первую очередь в бюджет Новой Каледонии, а не французского государства или частных акционеров. Национализация капитала компании “Никель” на уровне территории 
- важный шаг к поставленной канаками цели контроля природных ресурсов, поскольку это старейшее предприятие владеет ныне $3 / 4$ всех запасов никеля и половиной шахт в Новой Каледонии. В соответствии с этой же логикой НСФОК надеется в будущем передать шахты в управление местной структуре, которая сможет решать, каким из добывающих компаний давать концессии: в настоящее время эти компании являются хозяевами положения, подавая заявки на разработку месторождений в административные органы провинций.

\section{Трансформация никелевой промышленности}

Из перечисления достижений канаков в сфере никеля становится понятным, что выполнение их требований (создание ЮТГДК и затем Северного завода) заметно изменило картину новокаледонского никелевого сектора. На всем протяжении колониальной эпохи, с 1870-х до 1930-х гг. “Компания Никель” была монополистом. Она подчинила себе мелкие горнодобывающие компании, у руля которых стояли выходцы из метрополии или колонисты с других тихоокеанских островов. Число этих компаний то росло, то сокращалось подобно шагреневой коже в зависимости от конъюнктуры на рынке никеля, но все они работали на никелевого гиганта, находившегося, в свою очередь, под контролем банка Ротшильда. В период между двумя мировыми войнами эти “мелкие“ (в сравнении с “Никелем”) горнодобытчики впервые получили возможность самостоятельного экспорта - в частности, в Японию. Во время Второй мировой войны они практически исчезли, но после ее окончания появились вновь, и число их стало расти. В конце 1960-х гг., благодаря буму цен на никель, пятнадцать независимых компаний имели собственный экспорт и еще шесть работали по контракту с “Никелем” (Bencivengo 2014). Но в настоящее время “мелким горнодобытчикам" (которых осталось четыре) приходится иметь дело не только с “Никелем”, перешедшим тем временем в руки французского государства ${ }^{6}$; два других предприятия прочно заняли свое место: это металлургический филиал ЮТГДК и, на юге, мультинациональный бразильский промышленный комплекс “Ва́ли С. А.”, появившийся здесь в результате стремления противников независимости создать конкуренцию канакским предприятиям и поглотивший канадскую кампанию “Инко”. О создании на юге завода для обогащения местных руд (бедных никелем) речь шла с начала 1990-х гг., однако запущен он был только в 2002 г., когда лоялисты, управляющие Южной провинцией, поняли, что канаки смогут построить свой завод?.

Подобно тому, как на политической арене, благодаря Нумейскому соглашению, депутаты-канаки все больше набирают вес, рост ЮТГДК стал источником серьезных изменений в соотношении сил в экономике, прямо или косвенно способствуя появлению нескольких местных и офшорных металлургических проектов, а также “каледонизации” самой Компании “Никель”, прежде опиравшейся на колониальную власть. Но можно ли сказать, что, выведя на сцену новых игроков на рынке никеля, ЮТГДК стала на нем ключевым игроком, каким прежде был “Никель”, способный поглощать более мелкие предприятия, заставить их работать на себя как арендаторов и контролировать их экспорт?

Чтобы ответить на этот вопрос, нужно начать с того, что “Никелю” и сегодня еще принадлежат 53\% ценных бумаг горнодобывающих компаний, а ЮТГДК, хотя и быстро и далеко продвинувшейся на рынке, - только 13\%, тогда как на долю одного из старых “малых предприятий” приходится 16\% - таким образом, оно находится на втором месте после “Никеля”; металлургический филиал ЮТГДК приносит компании дополнительно еще 4\% ценных бумаг, при том что “Ва́ли С. А.” владеет 8\% (Syndex 2016: 42). Надо отметить также, что под “малыми горнодобывающими предприятиями” сегодня подразумеваются компании 
с оборотом от 1 до 5 миллиардов тихоокеанских франков ${ }^{8}$, что делает их значительными игроками.

Однако заданный вопрос предполагает не только чисто экономический ответ. Во-первых, несмотря на то, что “канакское предприятие” становится все менее “канакским” по мере его расширения и интернационализации - а возможно даже, именно благодаря этому, - оно уже почти выиграло символическое пари, доказав, что независимость Новой Каледонии возможна не только потому, что никель может приносить прибыль (как провинции, так и “стране” в целом), но и потому, что канаки, в сотрудничестве с транснациональными союзниками, способны управлять экономикой не хуже не канаков.

Фронту освобождения канаков удалось переориентировать никелевую промышленность, сделав ее мотором развития “страны”, о чем убедительно свидетельствует создание Каледонской промышленной акционерной компании, вернувшей “стране” акции государства и “Компании Никель”. Эта переориентация идет параллельно с политической динамикой Нумейского соглашения, которое как минимум (в понимании лоялистов) положило начало постепенной автономизации территории благодаря передаче ей все более широких полномочий; как максимум же (в понимании большинства канаков и в меньшей степени не канаков) должно завершиться достижением независимости. Как уже было сказано, согласно Нумейскому соглашению, развитие горнодобывающей промышленности как основы экономической эмансипации было увязано с эмансипацией институциональной. В этих условиях сильнейшей политизации проблемы добычи никеля, связанной с требованием независимости, и появились в 2009 г. План разработки минеральных ресурсов и Кодекс горного дела, регламентирующие горнодобывающую деятельность. Они предусматривают, в частности, меры по охране окружающей среды при разработке месторождений, по развитию промышленности, ориентированной на работу с невозобновляемыми ресурсами, а также экспортную политику. Таким образом, НСФОК, несомненно, прочно утвердил такую организацию никелевой промышленности, которая подчиняется логике автономизации страны и ее освобождения от французской опеки.

Тем не менее, все это еще не означает наличия четко очерченной политической стратегии в сфере никеля. Последняя неоднократно обсуждалась в период между 2010 и 2013 гг. Стратегическим промышленным комитетом, в который вошли представители сторон, подписавших Нумейское соглашение, и представители местных администраций трех провинций, а позднее - специально созданной Рабочей группой с участием президентов трех провинций, но переговоры шли трудно и были приостановлены накануне референдума 2018 г. (Demmer 2018), который продемонстрировал реальное соотношение сил и возможностей каждого лагеря - лоялистов и сепаратистов - разыгрывать свою карту в этой игре (Demmer et al. 2018). Со стороны канаков, впрочем, заметна решимость позволить ЮТГДК и в меньшей степени - “Никелю” контролировать местный рынок ценного металла, принуждая “мелких горнодобытчиков” продавать сырье местным или офшорным заводам. Мы увидим в заключение, что этой стратегии пока далеко до воплощения и одновременно получим еще один ответ на поставленный выше вопрос относительно места, занимаемого ЮТГДК в добыче и переработке новокаледонского никеля.

\section{Битва за экспорт, или трудности воплощения канакской никелевой стратегии}

С 2015 г. никелевая стратегия НСФОК носит официальное название "Никелевой доктрины”. Она идет дальше в направлении национализации никеля по сравнению с существующим 
Планом разработки минеральных ресурсов, хотя последний уже устойчиво переориентировал сектор на реинвестиции доходов от добычи, переработки и экспорта никеля в развитие территории, продолжая тем самым принципы, заложенные в Нумейском соглашении. Новая доктрина есть ни больше, ни меньше чем подтверждение традиционной ориентации сепаратистов, ныне делающих основной акцент на необходимости переработки никеля на металлургических предприятиях, большая часть капитала которых принадлежит Новой Каледонии, обращая это требование к каледонским горнякам, экспортирующим сырье. Это объясняется тем, что прибавочная стоимость местных предприятий будет оставаться в стране, что позволит в перспективе диверсифицировать экономику с прицелом на после-никелевую эру (впрочем, до нее еще как минимум лет 50). Доктрина исходит из возможности полного исчерпания ресурсов каледонского никеля, поскольку предполагает в дальнейшем закупку сырья за границей (в частности, в Индонезии и на Филиппинах) для переработки его на каледонских заводах. Это означает, что сепаратисты будут продолжать развивать международное партнерство в интересах местного развития, тем более, что для продления эксплуатации никелевых месторождений потребуется перерабатывать все менее богатые руды, а значит, понадобятся заводы с соответствующим оборудованием. Создатели никелевой доктрины делают ставку на постепенное полное прекращение экспорта сырья, которое должно, по их плану, перерабатываться целиком на местных заводах, как действующих, так и будущих 9 . Однако для того, чтобы ЮТГДК могла развивать международное партнерство, необходимо, чтобы добывающие предприятия играли по этим правилам и продавали свое сырье ее партнерам, а не искали собственные рынки сбыта.

В настоящее время борьба сепаратистов далека от победы. Противники никелевой доктрины утверждают, что офшорная модель не так выгодна, как переработка сырья на месте, и к тому же она ведет к быстрому исчерпанию рудных запасов, поскольку требует выполнения контрактов на поставку больших количеств никеля. Кроме того, экспортеры сырья считают, что НСФОК скорее действует в интересах ЮТГДК (главного игрока в международных проектах), нежели обеспечивает выгоду от никелевой ренты для “страны”. Наконец, они ссылаются на принцип свободного рынка. В то же время действующий План разработки минеральных ресурсов, гарантируя экспортерам некоторую независимость от местных переработчиков, в то же время рекомендует им сохранять верность “традиционным” клиентам. Несколько лет назад бурные дебаты были вызваны запросом на поставку никеля со стороны Китая, не являющегося “традиционным” клиентом. Они выплеснулись и в политическую сферу: большая часть лоялистов выступала за свободу торговли против НСФОК и его союзника - автономистской партии "Единая Каледония", защищавших принцип, заложенный в План, и заодно - проект возможного сотрудничества ЮТГДК с Китаем (Demmer 2017: 130-140).

Конфликт разворачивался между 5 и 28 августа 2015 г. На первый взгляд его сторонами были профсоюз горняков-водителей ContraKmine и правительство Новой Каледонии. Обеспокоенные сохранностью своих рабочих мест, члены профсоюза (хозяева машин, субподрядчики и обычные водители, в основном канаки) вышли на улицы, отказываясь выполнять задание экспортных компаний по отгрузке низкообогащенной руды в Китай. Правительство в лице Комитета внешней торговли рудными ресурсами (Comitéducommerce extérieur minier-CCЕМ) попыталось ориентировать “мелких горнодобытчиков” на традиционного клиента из Австралии, несмотря на то, что последний, испытывая финансовые затруднения, заморозил закупочные цены на пять лет. В свою очередь НСФОК организовал Комитет в поддержку никелевой доктрины, настаивая на необходимости сохранить бедную руду на будущее, в ожидании подписания партнерского соглашения с одной из китайских литейных компаний по переработке низкообогащенного сырья. По истечении двух с половиной недель перекрытия баррикадами бастующих основных 
магистралей профсоюзу был предложен первый согласительный протокол. Председатель правительства пообещал отменить решение об экспорте по заявке японского литейного предприятия Сумитомо и согласовать с профсоюзами заявки другого японского предприятия Памко. Что же касается Китая, то здесь горняки добились лишь обещания нового рассмотрения их дела и помощи в согласовании договоров с австралийским клиентом. Сочтя эти гарантии недостаточными, забастовщики продолжили свои выступления. Только смертельное ДТП при столкновении автомобиля с баррикадой и посредничество президента Каледонского союза положили конец конфликту на условиях, почти не отличавшихся от первоначальных.

Но история на этом не закончилась. Методы обогащения руды с содержанием никеля менее 1,65\% обсуждались на чрезвычайной сессии Конгресса. 14 октября 2015 г. депутаты 27 голосами против 25 при двух воздержавшихся постановили, что План разработки минеральных ресурсов не запрещает экспорт нетрадиционным клиентам, в том числе Китаю, как было решено поначалу и на чем был основан отказ. Таким образом "мелкие горнодобытчики” и “Компания Никель” временно получили разрешение на экспорт бедной руды в Китай. Возможны разные объяснения такого исхода конфликта: или кризис, в котором находился мировой рынок никеля с 2011 г., по причинам чисто прагматического свойства возобладал над стремлением канакского горняцкого национализма контролировать экспорт, или в конфликте присутствовало другое, в большей мере идеологическое измерение: столкновение между либеральным видением управления сектором и кейнсианской концепцией, лучше совместимой с эмансипацией “страны”, к которой стремится НСФОК, или, наконец, мобилизация горняков была направлена на дестабилизацию работы ЮТГДК и ее экономической модели в целом. Как бы то ни было, в ходе этого конфликта горняки-водители и экспортеры сырья оказались в центре политической борьбы, поставив под сомнение политико-экономический подход сепаратистов, зародившийся в сфере добычи никеля и забуксовавший в институциональном поле.

То, что проблему административного разрешения, относящуюся к ведению Комитета внешней торговли, удалось довести до рассмотрения Конгрессом (тогда как регулирующие компетенции в сфере никеля принадлежат представителю правительства), убедительно свидетельствует о взаимопроникновении политики и экономики в Новой Каледонии.

\section{Незавершенная деколонизация}

Рассматриваемый конфликт говорит также о том, на какой стадии деколонизации находится Новая Каледония. План разработки минеральных ресурсов является достижением канаков на пути к обретению местного контроля над ресурсами, однако борьба на других направлениях еще продолжается.

Если до сих пор экспорт следовал по каналам, предписанным Планом разработки минеральных ресурсов, то после выступлений горняков-водителей ситуация изменилась: вслед за первыми разрешениями последовали другие контракты с китайскими предприятиями. Открыв новый канал экспорта, к тому же постановлением Конгресса, а не проходным решением Комитета внешней торговли, эта мобилизация способствовала изменению философии Плана, который пытается сохранить существующий баланс между горнодобывающими предприятиями, ограничивая легальные пути сбыта. Во всяком случае, она показала, что никелевую доктрину пока не удается навязать всему обществу.

Сказать, что сепаратисты - не единственные распорядители новокаледонских ресурсов, - это ничего не сказать. Им приходится договариваться с неканаками, с которыми они давно 
составляют единый народ (Demmer 2018). Их задача - выстроить прочные союзы и/или завоевать большинство в местных органах власти. И даже если решение конгресса по экспорту в 2015 г. не повторяет в точности то, что чаще всего происходит на политической арене, расколотой по квазиэтническому принципу на сепаратистов и лоялистов, тем не менее, историческое наследие колонии-поселения до сих пор оказывает давление на соотношение сил в местной политической жизни и мешает НСФОК утвердить собственную никелевую стратегию. Напрасно защитники никелевой доктрины организовывали на всем протяжении 2016 г. конференции, посвященные стратегии ЮТГДК, и объясняли, как невыгодно продавать сырье в период спада цен на рынке, как это противоречит принципам ответственного управления ресурсами, заложенным в основу Плана разработки минеральных ресурсов, напрасно пытались через суд отменить правительственное решение, позволяющее компании Балланд - семейному предприятию выходцев из метрополии - продавать сырье японской литейной компании Сумимото (Nouvelles 2016) - все это не дало никаких результатов. Исход битвы за продвижение идей канаков в местные органы управления остается неясным в ситуации, когда автохтонное население, хотя и занимается бизнесом, но остается в меньшинстве (его доля составляет 39\%, а в Конгрессе только 24 депутата из 54 представляют Фронт освобождения канаков).

О незавершенности деколонизации можно судить и по тому, что решения, принятые в первые месяцы после завершения конфликта, свидетельствуют со всей очевидностью о достаточно широкой автономии Новой Каледонии, но отнюдь не о ее независимости от французской опеки. Хотя государство и согласилось подкрепить Нумейское соглашение Планом разработки минеральных ресурсов, тем самым подчеркивая передачу этого вопроса, как и других неисключительных полномочий, на уровень территории, состоявшееся в феврале 2016 г. XIV заседание Комитета сторон, подписавших соглашение, показало, что французское государство остается действующим игроком, намеренным регулировать различные составляющие новокаледонской политической жизни. Собирая ежегодно за круглым столом, в метрополии, политических представителей “страны”, этот комитет зафиксировал кризис цен на никель и проблемы каледонской никелевой промышленности. Принятый в марте 2016 г. “План экономической поддержки горно-металлургической деятельности” не только вылился в существенную финансовую помощь “Компании Никель” и позволил пересмотреть планы экспорта в Китай, но и настоятельно рекомендовал добывающим предприятиям поддержать ЮТГДК в снабжении южнокорейского завода, которому она пообещала больше сырья, чем реально могла поставить. После чего дальнейшие дискуссии по никелевой стратегии были отложены до окончания кризиса - так же, как в предыдущий раз их откладывали до референдума. Теперь пришло время возобновить диалог. 


\section{Примечания}

1 Северная провинция населена канаками на 70\%, а о-ва Луайоте - на 95\%. Несмотря на то, что 40\% от всего канакского населения живет в большом Нумеа на юге острова, где сосредоточены $2 / 3$ его обитателей, доля канаков в Южной провинции составляет всего 26\%, более $33 \%$ - выходцы из метрополии и потомки колонизаторов, остальные - приезжие с других тихоокеанских островов, а также из Индонезии и Вьетнама (Recensement ISEE de 2014). Концепция восстановления экономического равновесия 1988 г. предполагала перераспределение бюджета территории в пользу Северной провинции и о-вов Луайоте, чтобы они получили в свое распоряжение более существенные средства, чем полагалось в соответствии с численностью их населения. Она также сделала возможной финансовую помощь государства, направляемую на проекты в области развития.

2 Местное правительство - коллегиальный орган, избираемый Конгрессом напрямую по системе списков пропорционального представительства. Конгресс, в свою очередь, состоит из 54 депутатов трех провинциальных ассамблей (15 из 22 членов от Северной провинции, 32 из 40 членов от Южной провинции и 7 из 14 членов от Провинции островов Луайоте). Таким образом, сторонники независимости составляют среди депутатов меньшинство.

3 Оставшиеся 25\% капитала SOFINOR принадлежат Каледонийскому акционерному институту и делятся между Французским агентством развития и тремя провинциями, каждая из которых владеет $16 \%$ акций.

4 В 2001 г. местные предприятия с народным участием насчитывали около 700 мелких акционеров, что составляет около 15\% взрослого населения провинции (Pitoiset 2002).

51000 тихоокеанских франков $=8,35$ евро.

6 В 1974 “Компания Никель” вошла в группу Imetal, главным акционером которой был все тот же банк Ротшильд. В 1987 г. она стала 100\% каледонским филиалом никелевого подразделения группы Eramet.

7 Несмотря на то, что на этом заводе (Гороникель/Goronickel), работает много канаков и у него есть местные субподрядчики, только 5\% его акций принадлежат провинции, остальные - частным вкладчикам.

8 Цифры взяты из документа, озаглавленного “К вопросу о ситуации на предприятиях горнодобывающей промышленности в Новой Кадежонии”, распространявшегося в мае 2016 г. на собрании представителей Профсоюза экспортеров никеля.

9 Отметим, что ныне действующие заводы освобождены от налогов и сборов вплоть до достижения ими рентабельности, согласно закону, принятому в 2001 - 2002 гг. с целью привлечь иностранных инвесторов.

Пер. с фр. Е.И. Филипповой

\section{Источники и материаль}

CEROM 2015. La croissance pénalisée par la demande intérieure. Étude Comptes Économiques Rapides de l'Outre-Mer, 2015.

Demmer C. 2018. Un peuple calédonien? Le référendum d'autodétermination en Nouvelle-Calédonie, La vie des idées, mars $2018:$ https://laviedesidees.fr/_Demmer-Christine_html

Demmer et al. 2018 - Demmer C., Le Meur P.-Y., Sourisseau J.-M. Quelle stratégie nickel après le référendum d'indépendance?, Médiapart, 30 octobre 2018. https://blogs.mediapart.fr/edition/les-invites-de-mediapart/article/301018/quelle-strategie-nickel-apres-le-referendum-d-independance

Exportations 2015. Exportations vers des fondeurs étrangers vs usine off-shore: même performance? Le nickel et la Calédonie, 2015, 03. $10 \mathrm{http} / / / \mathrm{www} \cdot b l o g s m s p . n c / e x p o r t a t i o n s-v e r s-d e s-f o n d e u r s-e t r a n g e r s-v s-$ usine-off-shore-meme-performance/

Nouvelles 2016. Les Nouvelles Calédoniennes, journal du 05-05-2016.

Syndex 2016. Nickel, métal du diable ou vecteur du développement, Rapport Syndex, 2016, p. 42. 


\title{
Научная литература
}

Bencivengo Y. Nickel. La naissance de l'industrie. Tours: PUFR, 2014.

David C., Sourisseau J.-M. De Matignon à la consultation sur l'indépendance: une trajectoire politique et institutionnelle originale // La Nouvelle-Calédonie face à son destin: Quel bilan à la veille de la consultation sur la pleine souveraineté? / Eds. S. Bouard, J.-M. Sourisseau, V Geronimi, S. Blaise, L. Ro’i. Paris: Karthala, 2016. P. 23-69.

Demmer C. Socialisme kanak, une expérience politique à Canala (Nouvelle-Calédonie. Paris: Karthala, 2016.

Demmer C. L'export du nickel au cœur du débat politique néo-calédonien // Mouvements. 2017. Vol. 91 (3). P. $130-140$.

Freyss J. Économie assistée et changement social en Nouvelle-Calédonie. Paris: PUF, 1995.

Pitoiset A. L'actionnariat populaire en province Nord de la Nouvelle-Calédonie. Société de profit dans une société de partage. Mémoire de DEA en Anthropologie économique, Nouméa: Université de Nouvelle-Calédonie, 2002.

Rese a r ch Article

Demmer, C. Kanak mining nationalism and "positioning" of mining and metallurgic companies in Nouvelle-Calédonie [Gorniatskii natsionalizm, nikelevaia promyshlennost' i dekolonizatsiia v Novoi Kaledonii] Anthropologies, 2021, no 1, pp. 49-61 https://doi.org/10.33876/2782-3423/2021-1/49-61

\section{(C) Institute of Ethnology and Anthropology RAS}

Christine Demmer | https://orcid.org/0000-0001-6998-0746 | CNRS, Centre Norbert Elias, 2 rue de la Charité, 13002 Marseille, France | christine.demmer@univ-amu.fr

\section{Keywords}

Nouvelle-Calédonie, Kanaks, decolonization, Nouméa agreement, economic rebalancing, control over resources, nickel industry, mining nationalism, kanak socialism, referendum

\begin{abstract}
This article aims to explain that the mine in New Caledonia is for the Kanaks a "grassroots experience" of a decolonization initiated at the same time in institutions since about thirty years. It reminds the steps and the shapes of nickel conquest by independentists, which is the main economic resource of the archipelago. It highlights that the control of a multinational - SMSP - has profoundly reconfigured the mining sector, imposing new giant metallurgical firms against local export of ore firms. Based on contemporary mining landscape description, it examines as a mirror effect the singular decolonization situation going on in this 'Overseas Country' at the time of self-determination referendums closing the emancipation process acted in the "Nouméa agreement" of 1998.
\end{abstract}

\section{References}

Bencivengo, Y. 2014. Nickel. La naissance de l'industrie calédonienne [Nickel. The birth of the Caledonian industry]. Tours: PUFR.

David, C. et J.-M. Sourisseau. 2016. De Matignon à la consultation sur l'indépendance: une trajectoire politique et institutionnelle originale [From Matignon to the consultation on independence: an original political and institutional trajectory]. in Bouard S., Sourisseau J.-M., Geronimi V., Blaise S., Ro'i L. (eds), La Nouvelle-Calédonie face à son destin: Quel bilan à la veille de la consultation sur la pleine souveraineté? Paris: Karthala: 23-69.

Demmer, C. 2016. Socialisme kanak, une expérience politique à Canala (Nouvelle-Calédonie) [Kanak socialism, a political experiment in Canala, Nouvelle-Calédonie]. Paris: Karthala. 
Demmer, C. 2017. L'export du nickel au cœur du débat politique néo-calédonien [The export of nickel at the heart of the New Caledonian political debate], Mouvements, 91, 3: 130-140.

Freyss, J. 1995. Économie assistée et changement social en Nouvelle-Calédonie [Assisted economy and social change in Nouvelle-Calédonie], Paris: PUF.

Pitoiset, A. 2002. L'actionnariat populaire en province Nord de la Nouvelle-Calédonie. Société de profit dans une société de partage [Popular shareholding in the northern province of New Caledonia. Profit society in a sharing society]. Mémoire de DEA en Anthropologie économique, Nouméa: Université de Nouvelle-Calédonie. 